\title{
Visualization of the thymus by substance $P$ receptor scintigraphy in man
}

\author{
P.M. van Hagen 1,2, W.A.P. Breeman³, J.C. Reubi5, P.T.E. Postema², P.J. van den Anker-Lugtenburg4, \\ D.J. Kwekkeboom ${ }^{3}$, J. Laissue ${ }^{5}$, B. Waser ${ }^{5}$, S.W.J. Lamberts 2 , T.J. Visser2, E.P. Krenning ${ }^{2,3}$ \\ ${ }^{1}$ Department of Immunology, Erasmus University Rotterdam, The Netherlands \\ 2 Department of Internal Medicine III, Erasmus University Rotterdam, The Netherlands \\ 3 Department of Nuclear Medicine, Erasmus University Rotterdam, The Netherlands \\ 4 Department of Hematology, Erasmus University Rotterdam, The Netherlands \\ 5 Department of Pathology, University of Berne, Switzerland
}

Received 24 February and in revised form 23 May 1996

\begin{abstract}
Substance P, an 11-amino acid neuropeptide, has an important role in modulating pain transmission through neurokinin 1 and 2 receptors. Substance $P$ and other tachykinins may also play a role in the pathogenesis of inflammatory diseases. In this study we present the results concerning the metabolism of the substance $P$ analogue [111 $\mathrm{In}$-DTPA-Arg ${ }^{1}$-substance $\mathrm{P}$ in man, as well as the visualization of the thymus in patients with immune-mediated diseases. Twelve selected patients were investigated, comprising five with inflammatory bowel disease, one with ophthalmic Graves' disease, one with sclerosing cholangitis, one with Sjögren's syndrome, one with rheumatoid arthritis, one with systemic lupus erythematosus and two with myasthenia gravis. During and after intravenous administration of $150-250 \mathrm{MBq}$ $(2.5-5.0 \mu \mathrm{g})\left[{ }^{111} \operatorname{In}-D T P A-A^{1}{ }^{1}\right]$-substance P, blood pressure, heart rate and oxygen saturation were monitored. Radioactivity was measured in blood, urine and faeces during the $48 \mathrm{~h}$ after injection. Planar and single-photon emission tomographic images were obtained 4 and $24 \mathrm{~h}$ after injection. After administration of [111 In-DTPAArg ${ }^{1}$-substance $\mathrm{P}$, a transient flush was observed in all patients. Degradation of [ ${ }^{111}$ In-DTPA-Arg $\left.{ }^{1}\right]$-substance P started in the first minutes after administration, resulting in a half-life of $10 \mathrm{~min}$ for the total plasma radioactivity, and of $4 \mathrm{~min}$ for the intact radiopharmaceutical, as identified with high-performance liquid chromatography. Urinary excretion accounted for $>95 \%$ of the radioactivity within $24 \mathrm{~h}$ post injection, and up to $0.05 \%$ was found in the faeces up to $60 \mathrm{~h}$. In all patients uptake of radioactivity was found in the areolae mammae (in women), liver, spleen, kidneys and urinary bladder. In eight patients a high uptake of [111 In-DTPA-Arg ${ }^{1}$-substance $P$ was observed in the thymus. We conclude that, despite its short
\end{abstract}

Correspondence to: P.M. van Hagen, Department of Immunology and Internal Medicine III, Dijkzigt University Hospital Rotterdam, Dr. Molewaterplein 40, 3015 GD Rotterdam, The Netherlands half-life, $\left[{ }^{111} \mathrm{In}\right.$-DTPA-Arg $\left.{ }^{1}\right]$-substance $\mathrm{P}$, a new radiopharmaceutical, can be used to visualize the thymus. This may contribute to the investigation of the role of thymus in immune-mediated diseases. In addition, inflammatory sites in various diseases could be visualized.

Key words: Substance P - Thymus - Immune-mediated diseases - Inflammatory bowel disease

Eur J Nucl Med (1996) 23:1508-1513

\section{Introduction}

Substance $P$ is an 11-amino acid neuropeptide and is known as a powerful member of a family of tachykinins characterized by the $\mathrm{C}$ terminal sequence Phe-X-GlyLeu-Met- $\mathrm{NH}_{2}$ [1]. It has been well established that substance $\mathbf{P}$ plays an important role in modulating pain transmission from peripheral and central primary afferents through neurokinin 1 and 2 receptors. Substance P and other tachykinins may also play a role in the pathogenesis of inflammatory diseases [2-7]. Substance $P$ has been shown to induce degranulation of mast cells in vitro, to regulate chemotaxis, to release lysosomal enzymes from macrophages, and to regulate expansion of $\mathrm{T}$ and $\mathrm{B}$ cells and production of immunoglobulins [8-11]. The thymus seems to be involved in immune-mediated diseases. Lymphofollicular hyperplasia of the thymus has been described in autoimmune diseases such as myasthenia gravis, systemic lupus erythematosus, scleroderma, rheumatoid arthritis, Hashimoto's thyroiditis and Sjögren's syndrome [12-15].

Recently, substance $\mathrm{P}$ was detected in the outer cortex of the thymus and in the peptidergic neurons that innervate the thymus $[16,17]$. Specific substance $P$ binding sites were found in the rat thymus in association with the vessels and the medulla [18]. Large numbers of high-af- 
finity substance $P$ receptors were found in surgical specimens obtained from patients with inflammatory bowel disease. The substance $\mathrm{P}$ binding neurokinin 1 receptor is expressed by arterioles and venules located in the submucosa, muscularis mucosa, external longitudinal muscle and serosa [4].

We developed a scintigraphic technique using an indium-111 labelled substance $P$ analogue, [ ${ }^{111}$ In-DTPA$\left.\mathrm{Arg}^{1}\right]$-substance $\mathrm{P}$, to visualize affected tissues in immune disorders, e.g. the thymus. In this study results are presented concerning the metabolism of ${ }^{111} \mathrm{In}$-labelled [DTPA-Arg ${ }^{1}$-substance $\mathrm{P}$ and the scintigraphic detection of the thymus in immune-mediated diseases. This may contribute to our understanding of the role of the thymus in immune disorders.

\section{Materials and methods}

Patients. Twelve selected patients were investigated (with informed consent), five with inflammatory bowel disease, one with ophthalmic Graves' disease, one with sclerosing cholangitis, one with Sjögren's syndrome, one with rheumatoid arthritis, two with myasthenia gravis and one with systemic lupus erythematosus. The diagnosis was established according to the clinical presentation and histopathological examination of gastrointestinal biopsies in the patients with inflammatory bowel disease and by liver biopsy and endoscopic retrograde cholangiopancreatography in the patient with sclerosing cholangitis. In rheumatoid arthritis, Sjögren's syndrome and systemic lupus erythematosus the diagnosis was made according to the internationally accepted diagnostic criteria. The patient with Graves' disease had a lowered serum thyroidstimulating hormone concentration and elevated serum free thyroxine and specific thyroid-stimulating immunoglobulin concentrations. Uptake of radioactivity was investigated in six control patients, three with carcinoid tumours, one with carcinoma of the lung and two with malignant lymphomas. These patients received no oncological treatment, nor were they immunocompromised.

Radiopharmaceuticals. [DTPA-Arg ${ }^{1}$-substance $\mathrm{P}$ was labelled with $111 \mathrm{InCl}_{3}(370 \mathrm{MBq} / \mathrm{ml}$ in $\mathrm{HCl}$, pH $1.5-1.9$, Mallinckrodt, Petten, The Netherlands), up to a specific activity of $150 \mathrm{MBq}$ ${ }^{11} \mathrm{In}$ per $\mu \mathrm{g}$ [DTPA-Arg ${ }^{1}$ ]-substance P. Quality control by instant thin-layer chromatography (ITLC, Silica-gel) and SEP-PAK $C_{18}$ reversed-phase extraction were performed essentially as described previously [1.9, 20]. High-performance liquid chromatography (HPLC) was done using a Waters 600E multisolvent delivery system, connected to a $\mu$ Bondapak $\mathrm{C}_{18}$ reversed-phase column $(300 \times 3.9 \mathrm{~mm}$, particle size $10 \mu \mathrm{m})$. Elution was carried out at a flow of $1.5 \mathrm{ml}$ per minute with a linear gradient of $10 \%-50 \%$ acetonitrile in $0.1 \%$ trifluoroacetic acid in $30 \mathrm{~min}$, and the latter composition was kept constant for another $5 \mathrm{~min}$. The radiochemical purity of the radiolabelled substance $\mathrm{P}$ analogue was greater than $98 \%$. Although it is not excluded that additional groups of the peptide participate in ${ }^{111} \mathrm{In}$ complexation, the labelled product is referred to as [ ${ }^{11} \mathrm{In}$-DTPA-Arg']-substance P. The compound was stable for more than $4 \mathrm{~h}$ in the presence of the quencher gentisic acid at a final concentration of $2 \mathrm{mg}$ per $\mathrm{ml}$ and was competitive in radioligand displacement assays [19].

Substance $P$ receptor imaging. In our study $2.5-5.0 \mu \mathrm{g}\left[{ }^{111} \mathrm{In}-\right.$ DTPA-Arg']-substance P (150-200 MBq) was infused intrave- nously in $10 \mathrm{~min}$. In all patients blood pressure, heart rate and oxygen saturation of the blood were monitored. Planar and singlephoton emission tomographic (SPET) images were obtained with a large field of view gamma camera equipped with a medium-energy parallel-hole collimator. SPET analysis was performed with a Wiener filter on original data. Preset time for images obtained 4 , 24 and $48 \mathrm{~h}$ after injection of [ $\left.{ }^{111} \mathrm{In}-\mathrm{DTPA}-\mathrm{Arg}^{1}\right]$-substance $\mathrm{P}$ was 15 min. Planar images were obtained from the head and neck, chest, upper abdomen and lower abdomen. SPET studies were performed $4 \mathrm{~h}$ or $24 \mathrm{~h}$ after injection of the radiopharmaceutical.

Substance P receptor autoradiography. Substance P receptor autoradiography was performed as previously described [21, 22]. Iodine-125 labelled Bolton-Hunter substance P (BHSP) was used as ligand (2000 Ci/mmol; Anawa, Wangen, Switzerland). The slidemounted tissue sections were allowed to reach room temperature and then placed for $15 \mathrm{~min}$ in a pre-incubation medium of $50 \mathrm{mmol} / \mathrm{l}$ Tris- $\mathrm{HCl}, \mathrm{pH} 7.4$, at room temperature. The sections were then incubated for $60 \mathrm{~min}$, always at room temperature, in a solution of $50 \mathrm{mmol} / 1$ Tris- $\mathrm{HCl} \mathrm{pH}$ 7.4, containing BSA (200 mg/l), chymostatin (2 mg/l), leupeptin (4 mg/l), bacitracin

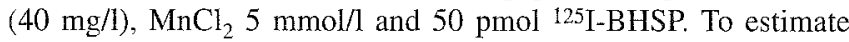
non-specific binding, paired serial sections were incubated as described above but $1 \mu \mathrm{mol} / \mathrm{l} \mathrm{SP}$ (Bachem, Bubendorf, Switzerland) was added to the incubation medium. Following this incubation the slides were rinsed 4 times, for $30 \mathrm{~s}$ each time, in ice-cold

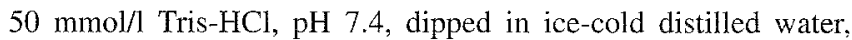
then quickly dried in a refrigerator under a stream of cold air. Sections were exposed to $\left[{ }^{3} \mathrm{H}\right]$-Ultrafilm (Amersham, UK) for 1 week.

Measurement of radioactivity in blood, urine and faeces. Radioactivity in blood, urine and faeces was measured with an LKB-1282Compugamma system or a GeLi-detector equipped with a multichannel analyser (Series 40, Canberra). Blood was collected in EDTA-containing tubes and immediately cooled on ice. Since substance $P$ is readily metabolized by various enzymes in blood, samples were immediately centrifuged at $0^{\circ} \mathrm{C}$, and plasma was fractionated on SEP-PAK $\mathrm{C}_{18}$ columns. Using the separation technique described previously [20], [111 In-DTPA-Arg ${ }^{1}$ ]-substance $P$ binds to SEP-PAK $\mathrm{C}_{18}$ stationary phase and is only eluted with ethanol, while ${ }^{111}$ In-DTPA is not retained on SEP-PAK $\mathrm{C}_{18}$ columns. The radioactivity in plasma and urine samples, which was eluted with ethanol from the SEP-PAK $\mathrm{C}_{18}$ column, is termed peptide-bound radioactivity, but was not further characterized. Blood samples were collected directly before and 2, 5, 10,20 and $40 \mathrm{~min}$ and 1, 4, 20 and $48 \mathrm{~h}$ after infusion. Urine was collected from the time of injection, initially at two intervals of $3 \mathrm{~h}$ and thereafter in intervals of $6 \mathrm{~h}$ until $48 \mathrm{~h}$ after injection. If feasible, faeces was collected until $72 \mathrm{~h}$ after injection. The chemical status of the radionuclide in blood and urine was analysed as a function of time using the SEP-PAK $\mathrm{C}_{18}$, HPLC and PD-10 gel filtration techniques as described previously $[19,20]$.

\section{Results}

After administration of ${ }^{111}{ }^{11}$ In-DTPA-Arg $\left.{ }^{1}\right]$-substance $\mathrm{P}$ a transient flush was observed in all patients. In one patient with Crohn's disease and anaemia, significant hypotension was observed associated with bradycardia. This patient recovered after $30 \mathrm{~s}$ in Trendelenburg's position, suggesting the presence of a vasovagal collapse. 


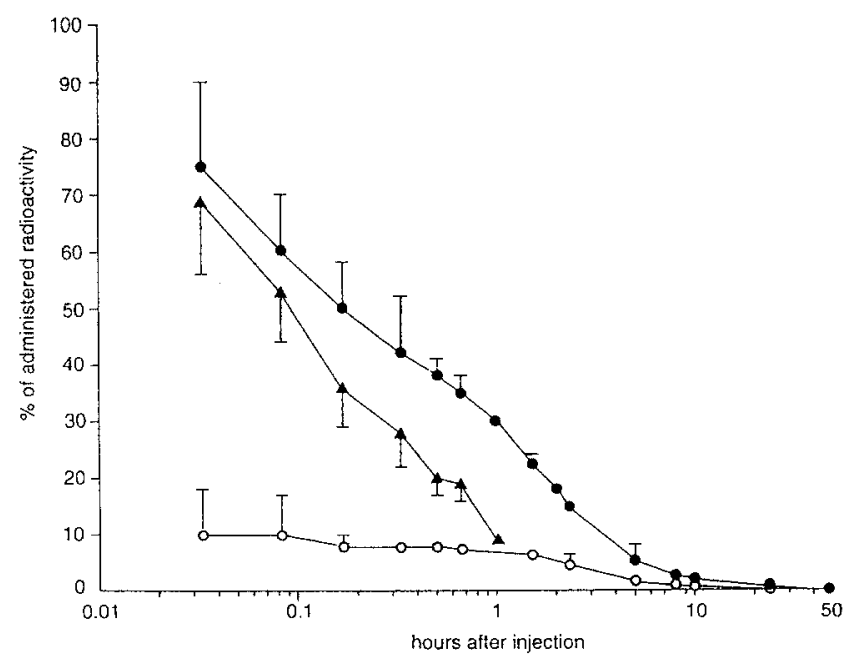

Fig. 1. Total plasma $(\boldsymbol{O})$, peptide-bound $(\boldsymbol{A})$ and cell-bound $(\bigcirc)$ radioactivity during the $48 \mathrm{~h}$ after injection

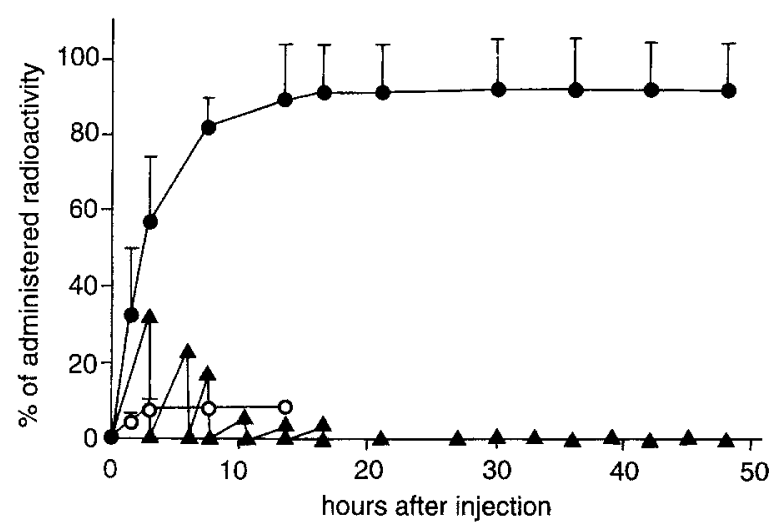

Fig. 2. Cumulative urinary excretion pattern of total (-) and peptide-bound $(\bigcirc)$ radioactivity during the $48 \mathrm{~h}$ after injection. The intersected line (A) shows the radioactivity in the urinary bladder
In Fig. 1 the time courses of total and peptide-bound radioactivity in plasma are presented until $50 \mathrm{~h}$ after administration. The average plasma radioactivity decreased rapidly after injection of [ ${ }^{111}{ }^{1}$ In-DTPA-Arg $\left.{ }^{1}\right]$-substance P. Degradation of [ ${ }^{111}$ In-DTPA-Arg $\left.{ }^{1}\right]$-substance P started in the first minutes after administration, resulting in a half-life of $10 \mathrm{~min}$ for total plasma radioactivity and of $4 \mathrm{~min}$ for the intact radiopharmaceutical, as identified with HPLC. Renal excretion resulted in the excretion of $>90 \%$ of the radioactivity in the urine within $24 \mathrm{~h}$ after injection, as shown in Fig. 2. Up to $0.05 \%$ was found in the faeces until $60 \mathrm{~h}$ after injection.

In all patients uptake of radioactivity was found in the liver, spleen and kidneys, as shown in Fig. 3. In addition, the urinary bladder, in women the areolae mammae, in four patients the lungs and in three patients the parotid glands were visualized. The uptake of radioactivity at these sites was supposed to be due to receptor binding (areolae, parotid glands and spleen) or to metabolism (liver, lungs, kidneys and urinary bladder) of the radiopharmaceutical. Deposition of radioactivity at other sites was considered to be due to other causes, which may be disease related (see Table 1). In eight patients a high uptake of [ ${ }^{111}$ In-DTPA-Arg $\left.{ }^{1}\right]$-substance $P$ was found in the thymus. The highest uptake of radioactivity in the thymus was observed in a patient with sclerosing cholangitis (Fig. 4). Computed tomographic scanning of the thorax confirmed an enlarged thymus. In the patients with systemic lupus erythematosus, ophthalmic Graves' disease and rheumatoid arthritis, and in two patients with inflammatory bowel disease, the thymus was visualized as well. In one patient with myasthenia gravis the thymus was visualized. In contrast, the other patient with myasthenia gravis, who was receiving high-dose corticosteroids, was negative at scintigraphy. No uptake of ra-
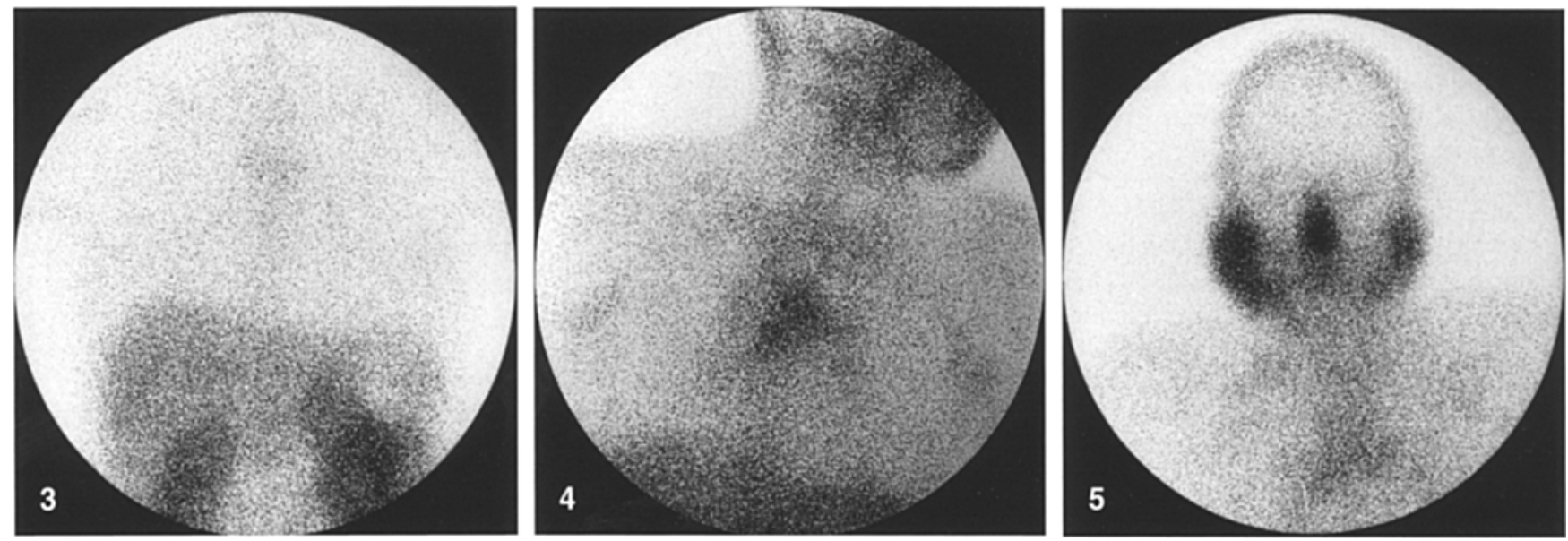

Fig. 3. Substance $P$ receptor scintigraphy of the upper abdomen and thorax in a patient with Crohn's disease (patient 9). Both kidneys, liver, spleen and a slight spot in the thorax resembling the thymus were visualized. (Anterior view, $24 \mathrm{~h}$ after injection)
Fig. 5. Substance $P$ receptor scintigraphy in a patient with Sjögren's syndrome (patient 13). In this patient uptake of radioactivity was found in the parotid glands, nose and thymus. (Anterior view, $24 \mathrm{~h}$ post injection)

Fig. 4. Accumulation of radioactivity in the thymus of a patient with sclerosing cholangitis, $24 \mathrm{~h}$ after injection (anterior view) 
Table 1. Substance P receptor scintigraphy: positive sites in controls and patients with autoimmune diseases

\begin{tabular}{llllll}
\hline Patient & Sex & Age & Diagnosis & Region & Sites positive by scintigraphya \\
\hline 1 & M & 56 & Hodgkin's disease & WB & Mouth, nose, lungs \\
2 & M & 34 & Non-Hodgkins lymphoma & WB & Lungs \\
3 & M & 55 & Carcinoid & WB & Lungs \\
4 & M & 36 & Carcinoid & WB & \\
5 & M & 33 & Carcinoid & WB & Parotid glands, mouth, nose \\
6 & M & 62 & Bronchus carcinoma & WB & Mouth, nose \\
7 & F & 24 & Crohn's disease & WB & Mouth, nose, abdominal spot \\
8 & F & 60 & Crohn's disease & WB & Thymus \\
9 & F & 30 & Crohn's disease & WB & Thymus, parotid glands, abdominal spot \\
10 & M & 40 & Ulcerative colitis & Partial & \\
11 & F & 39 & Ulcerative colitis & WB & \\
12 & M & 25 & Sclerosing cholangitis & WB & Thymus, abdominal spots \\
13 & F & 46 & Sjögren's syndrome & Partial & Thymus, parotid glands \\
14 & F & 72 & Rheumatoid athritis & Partial & Thymus, joints \\
15 & F & 34 & Graves' disease & Partial & Thymus, eye \\
16 & F & 32 & Systemic lupus erthematosus & Partial & Thymus, lungs \\
17 & F & 25 & Myasthenia gravis & Partial & Thymus \\
18 & M & 48 & Myasthenia gravis & Partial & \\
\hline
\end{tabular}

M, Male; F, female; WB, whole body

a In all patients uptake was found in the liver, spleen, kidneys and urinary bladder

dioactivity in the thymus or tumours was observed in the patients with carcinoid tumours $(n=3)$, lung carcinoma $(n=1)$ or malignant lymphomas $(n=2)$.

In addition to the thymus, in the patient with Sjögren's syndrome, the affected parotid glands showed a very high uptake of radioactivity (Fig. 5). In the patient with unilateral ophthalmic Graves' disease, high uptake of radioactivity was observed in the affected eye. The patient with rheumatoid arthritis revealed uptake of radioactivity in the affected joints. In two out of five patients with inflammatory bowel disease, accumulation of radioactivity was found at the sites of inflammation.

In vitro detection of specific substance $P$ receptors in the thymus from patients with myasthenia gravis was performed with substance $\mathrm{P}$ receptor autoradiography. As seen in Fig. 6, a high density of specific substance P binding sites was identified in this tissue. The localization of the receptors is not yet completely clear, but counterstaining of the sections for factor VIII immunohistochemistry suggests that the localization of some of the substance $\mathrm{P}$ receptors corresponds to that of the small vessels. However, it is probable that lymphoreticular cells also contain substance $P$ receptors.

\section{Discussion}

Substance $\mathrm{P}$ is found in the central nervous system as well as in peripheral neuronal circuits. In the peripheral nervous system substance $P$ is found in the primary afferent neurons (A-delta pain fibres and $\mathrm{C}$ fibres), which are involved in the transmission of noxious stimuli. Bioactive substance $P$ has been infused intravenously in hu- mans in doses of $0.5-1.5 \mathrm{pmol} \mathrm{kg-1} \mathrm{min}^{-1}$ over $60 \mathrm{~min}$ or $0.5-8.0$ pmol kg-1 $\mathrm{min}^{-1}$ over $20 \mathrm{~min}$ without serious side-effects $[23,24]$. A very short half-life of $1.6 \mathrm{~min}$ was measured, indicating a very high metabolic clearance. In normal plasma substance $P$ is degraded by enzymatic hydrolysis involving multiple proteases [25]. In this study the [DTPA-Arg ${ }^{1}$-substance $P$ was injected in patients with immune-mediated diseases. In one out of 12 patients hypotension was observed, with the clinical impression that a vasovagal collapse caused the hypotension. After administration of $\left[{ }^{111}\left[\mathrm{In}-\mathrm{DTPA}-\mathrm{Arg}^{1}\right]\right.$-substance $\mathrm{P}$ a transient flush was observed in all patients. Flushing by substance $\mathrm{P}$ is explained by vasodilatation of the blood vessels of the skin and indicates biological activity [24].

A very short half-life of $10 \mathrm{~min}$ for plasma radioactivity and of 4 min for the intact radiopharmaceutical was measured. Radioactivity was excreted almost exclusively by the kidneys, resulting in a low accumulation of radioactivity in the intestinal tract. Despite the high degradation rate of this radiopharmaceutical, it could visualize affected tissues. In eight patients with immune-mediated diseases the thymus was visualized. The present autoradiographic data undoubtedly showed the presence of specific substance $P$ receptors in the thymus from two non-scanned patients with an autoimmune disease. In the control patients, the thymus could not be visualized, suggesting a high receptor expression in immune-mediated diseases. Substance $P$ receptors have recently been reported to be present in the rat thymus, but their role is still obscure [18]. Substance P has been identified in nerve fibres of sensory origin in the thymus. The outer cortex of the human thymus contains a one- to two-cell- 

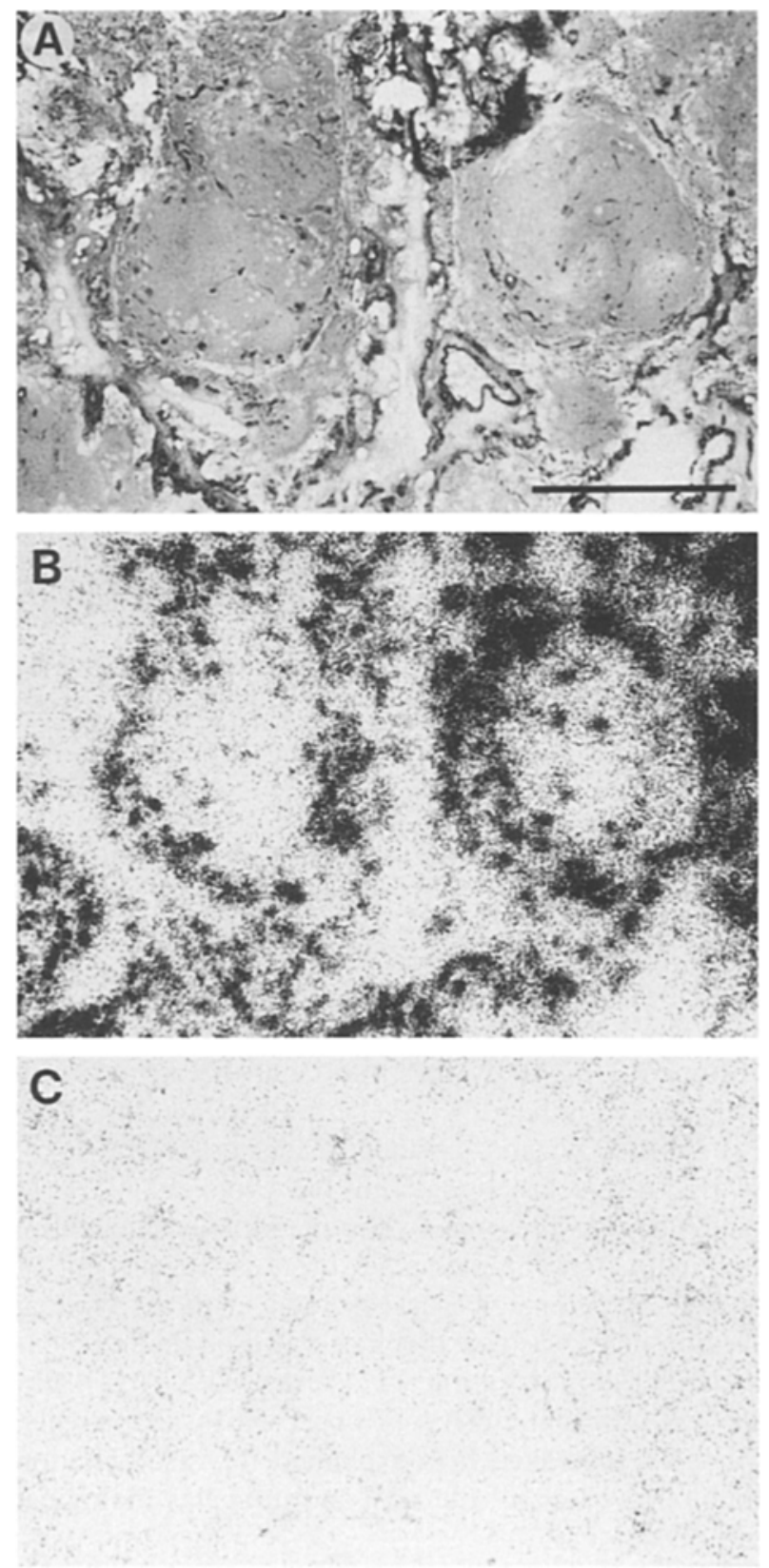

Fig. 6A-C. Substance P receptors in the thymus of a patient with myasthenia gravis, detected with in vitro receptor autoradiography. A Histological section, stained for factor VIII-like immunoreactivity. A high density of vessels surrounds a nodular aggregate of small lymphocytes, enclosing lymphatic follicles with germinal centres, and less densely cellular areas with Hassall's corpuscles. Bar=1 mm. B Total binding of 125 I-BHSP. Vessel-rich regions are labelled. Some lymphoreticular cells may also be labelled. C Nonspecific binding

thick layer that is immunoreactive with antisera against substance $P$. In this region the most immature and recently migrated thymocytes are found, emphasizing the role of neuropeptides in regulating the microenvironment for $T$ cell development [16]. The gene encoding both substance $\mathrm{P}$ and neurokinin $\mathrm{A}$ was shown to be expressed in rat thymus, especially in a subpopulation of cells in the medulla [26].
The thymus is known to play an important role in myasthenia gravis. The negative scintigram in one of the patients with myasthenia gravis may have been related to the use of high-dose corticosteroids, which are known to cause involution of the thymus. In $70 \%$ of cases, microscopy of thymuses of patients with myasthenia gravis revealed follicular hyperplasia of the medulla, containing germinal centres resembling an activated lymph node $[27,28]$. It may be that primary sensitization against the acetylcholine receptor, which plays a crucial role in myasthenia gravis, occurs in the thymus. The reason why substance $\mathrm{P}$ receptors are present in the thymus of patients with immune-mediated disease, as suggested in our patients, is obscure. However, their presence may mean that a similar process of sensitization as is hypothesized in myasthenia gravis takes place in other autoimmune diseases as well.

Besides the thymus, sites of inflammation in two patients with inflammatory bowel disease, the affected orbit in ophthalmic Graves' disease, the salivary glands in Sjögren's syndrome and the joints in rheumatoid arthritis were visualized. Although in patients with inflammatory bowel disease accumulation of radioactivity due to gut stenosis cannot be ruled out, the very low excretion of [ $\left.{ }^{111} \mathrm{In}-\mathrm{DTPA}-\mathrm{Arg}{ }^{1}\right]$-substance P into the bowel $(<0.05 \%)$ does not favour this explanation. Therefore, this accumulation is most likely due to the presence of substance $P$ receptors at the sites of inflammation in these patients, though we have no autoradiographic confirmation from the "scanned" patients. Substance P is supposed to be involved in inflammatory bowel disease, and upregulation of receptor binding sites at venules and muscle was previously shown by autoradiography [4]. In these patients a high expression of substance $P$ receptors was observed in comparison with control patients (1000-2000 times normal). Furthermore, substance $\mathrm{P}$ receptors have been reported in inflammatory synovitis in rat and humans [6]. 125I-labelled substance $P$ binding to microvascular endothelium paralleled the distribution of substance $P$ immunoreactive nerves and had the characteristics of the neurokinin 1 receptor [6].

In this study we have presented our preliminary results concerning the use of [111 In-DTPA-Arg ${ }^{1}$-substance $P$ as a new radiopharmaceutical with a very short halflife in the circulation. The thymus, which is usually involuted after puberty, expressed enough substance $\mathrm{P}$ receptors to allow in vivo visualization. The role of the thymus in autoimmune diseases is obscure, but enlargement of the thymus has been described in these diseases. Further investigations are necessary to evaluate the role of substance $\mathrm{P}$ receptor expression in the thymus in these diseases. In addition, inflammatory sites in various diseases could be visualized by substance $\mathrm{P}$ receptor scintigraphy. 


\section{References}

1. Chang MM, Leeman SE. Isolation of a sialogic peptide from bovine hypothalamic tissue and its characterization as substance P. J Biol Chem 1970; 245: 4784-4790.

2. Walsh DA, Salmon M, Wharton J, Mapp PI, Polak JM. Autoradiographic localisation and characterisation of substance $P$ binding sites in rat knees. Regul Pept 1993; 46: 189-192.

3. Walsh DA, Mapp PI, Salmon M, Rutherford RAD, Kidd BL, Revell PA, Balke DR, Polak JM. Localisation and characterisation of substance $\mathrm{P}$ binding to human synovium in rheumatoid arthritis. Ann Rheum Dis 1992; 51: 313-317.

4. Mantyh PW, Gates TS, Zimmerman RP, Welton ML, Passaro RP, Vigna SR, Maggio JE, Kruger L, Mantyh PW. Receptor binding sites for substance $\mathrm{P}$, but not substance $\mathrm{K}$, or neuromidin $K$, are expressed in high concentrations by arterioles, venules, and lymph nodes in surgical specimens from patients with ulcerative colitis and Crohn's disease. Proc Natl Acad Sci USA 1988; 85: 3235-3239.

5. Mantyh WM. Substance $P$ and the inflammatory and immune response. Ann NY Acad Sci 1991; 632: 263-271.

6. Walsh DA, Salmon M, Mapp PI, Wharton J, Garrett N, Blake DR, Polak JM. Microvascular substance P binding to normal and inflamed rat and human synovium. $J$ Pharmacol Exp Ther 1993; 267: 951-960.

7. Joyce TJ, Yood RA, Carraway RE. Quantitation of substance $\mathbf{P}$ and its metabolites in plasma and synovial fluid from patients with arthritis. $J$ Clin Endocrinol Metab 1993; 77: $632-637$.

8. Foreman JC, Jordan CC. Histamine release and vascular changes induced by neuropeptides. Agent Actions 1983; 13: $105-116$.

9. Ruff MR, Wahl SM, Pert CB. Substance P receptor mediated chemotaxis of human monocytes. Peptides 1985; 6: 107-111.

10. Payan DG, Brewster DR, Missirian-Bastian A, Goetzl EJ. Substance P recognition by a subset of human T lymphocytes. $J$ Clin Invest 1984; 74: 1532-1539.

11. Stanisz AM, Befus D, Bienenstock J. Differential effects of vasoactive peptide, substance $P$, and somatostatin on immunoglobulin synthesis and proliferations by lymphocytes from Peyer's patches, mesenteric lymph nodes, and spleen. $J$ Immunol 1986; 136: 152-156.

12. Rosai J, Levine GD. Tumors of the thymus. In: Atlas of tumor pathology, second series, fascicle 13. Washington DC: Armed Forces Institute of Pathology; 1976; 26-33; 133-137.

13. Levine GD, Rosai $\mathfrak{I}$. Thymic hyperplasia and neoplasia: a review of concepts. Human Pathol 1978; 9: 495-515.

14. Hoffmann WJ, Moller P, Otto HF. Thymic hyperplasia. II. Lymphoreticular hyperplasia of the thymus. An immunohistologic study. Klin Wochenschr 1987; 65: 53-60.

15. Tridente G. Immunopathology of the human thymus. Semin Hematol 1985; 22: 56-57.
16. Piantelli M, Maggiano N, Larocca LM, Ricci R, Ranelletti FO, Lauriola L, Capelli A. Neuropeptide-immunoreactive cells in the human thymus. Brain Behav Immun 1990; 4: 189-197.

17. Lorton D, Bellinger DL, Felten SY, Felten DL. Substance P innervation of the rat thymus. Peptides 1990; 11: 1269-1275.

18. Shigematsu K, Saavedra JM, Kurihara M. Specific substance $\mathrm{P}$ binding sites in rat thymus and spleen: in vitro autoradiographic study. Regul Pept 1986; 16: 147-156.

19. Breeman WAP, Van Hagen PM, Visser-Wisselaar HA, van der Pluijm ME, Koper JW, Setyono-Han B, Bakker WH, Kwekkeboom DJ, Hazenberg MP, Lamberts SWJ, Krenning EP. In vitro and in vivo studies of substance $\mathrm{P}$ receptor expression in rats with the new analog [indium-111-DTPA-Arg ${ }^{1}$ ] substance P. I Nucl Med 1996; 37: 108-117.

20. Breeman WAP, Hofland LJ, van der Pluijm M, Koetsveld PM, deJong M, Setyono-Han B, Bakker WH, Kwekkeboom DJ, Visser TJ, Lamberts SWJ, Krenning EP. A new radiolabelled somatostatin analogue [111 In-DTPA-D-Phe']RC-160: preparation, biological activity, receptor scintigraphy in rats and comparison with [ ${ }^{111}$ In-DTPA-D-Phe $\left.{ }^{1}\right]$ octreotide. Eur J Nucl Med 1994; $21: 328-335$.

21. Reubi JC, Mazzuccheli L, Laissue J. Intestinal vessels express a high density of somatostatin receptors in human inflammatory bowel disease. Gastroenterology 1994; 106: 951-959.

22. Hennig IM, Laissue JA, Horisberger U, Reubi JC. Substance $\mathbf{P}$ receptors in human primary neoplasms: tumoural and vascular localisation. Int J Cancer 1995; 61: 786-792.

23. Coiro V, Capretti L, Volpi R, Davoli C, Marcato A, Cavazzini U, Caffarri G, Rossi G, Chiodera P. Stimulation of ACTH/cortisol by intravenously infused substance $P$ in normal men: inhibition by sodium valproate. Neuroendocrinology 1992; 56: 459-463.

24. Schaffalitzky De Muckadel OB, Aggestrup S, Stentoft P. Flushing and plasma substance $\mathrm{P}$ concentration during infusion of synthetic substance $\mathrm{P}$ in normal men. Scand $J$ Gastroenterol 1986; 21: 498-502.

25. Mussap CJ, Gerargthy DP, Burcher E. Tachykinin receptors: a radioligand binding perspective. Review. J Neurochem 1993; 60: 1987-2009.

26. Ericsson A, Geenen V, Robert F, Legros JJ. Expression of preprotachykinin-A and neuropeptide- $Y$ messenger RNA in the thymus. Mol Endocrinol 1990; 4; 1211-1214.

27. Vincent A, Newson-Davis J, Newton P, Beck N. Acetylcholine receptor antibody and clinical response to thymectomy in myasthenia gravis. Neurology 1983; 33: 1276-1282.

28. Kuks JBM, Oosterhuis HJGH, Limburg PC, The TH. Antiacetylcholine receptor antibodies decrease after thymectomy in patients with myasthenia gravis. Clinical correlations. $/$ Autoimmun 1991; 4: 197-211. 